\title{
Les métamorphoses du poisson
}

Jacqueline Matras-Guin

\section{(2) OpenEdition}

Journals

Édition électronique

URL : https://journals.openedition.org/tc/381

DOI : $10.4000 /$ tc.381

ISSN : 1952-420X

\section{Éditeur}

Éditions de l'EHESS

\section{Édition imprimée}

Date de publication : 1 avril 1999

ISSN : 0248-6016

\section{Référence électronique}

Jacqueline Matras-Guin, «Les métamorphoses du poisson », Techniques \& Culture [En ligne], 31-32 |

1999, mis en ligne le 26 octobre 2005, consulté le 29 septembre 2022. URL : http://

journals.openedition.org/tc/381; DOI : https://doi.org/10.4000/tc.381

Ce document a été généré automatiquement le 29 septembre 2022

Tous droits réservés 


\section{Les métamorphoses du poisson}

Jacqueline Matras-Guin 